\title{
ANALYZING COMMON LANGUAGE ERRORS IN CLASSROOM COMMUNICATION OF ENGINEERING TEACHERS - AN EMPIRICAL STUDY
}

\author{
Dr. Madhavi Kesari \\ Associate Professor \& Head, Department of Humanities and Social Sciences, \\ National Institute of Technology Warangal, Telangana, India
}

\begin{abstract}
This paper reports the findings from the study that assessed common English language errors in classroom communication of engineering teachers by conducting pre and post tests using $T$ and $Z$ tests. The study used four language parameters in teaching (LPT) in terms of introduction(I), methodology(M), use of technology enabled sources (TES) and non verbal communication (NVC). The study was conducted in three stages. Firstly an analysis of common errors in teaching was made in the pre test, through video recordings; secondly the teachers were trained/orientated in the effective use of classroom techniques in terms of language functions. Finally during the post test teachers lectures were recorded and found that the errors were minimized. The data was statistically analysed on the basis of testing of hypothesis. There was a significant difference noticed in the use of language functions used by the teachers in which the female teachers reported using language functions more effectively than that of male teachers. Thus, the study identifies common errors in teaching also suggesting effective techniques for classroom teaching, developing effective communication skills.
\end{abstract}

Key words: English language errors; classroom communication; methodology; language functions; effective communication skills; common errors.

Cite this Article: Madhavi Kesari, Analyzing Common Language Errors in Classroom Communication of Engineering Teachers- An Empirical Study, International Journal of Management (IJM), 11(6), 2020, pp. 2199-2207.

https://iaeme.com/Home/issue/IJM?Volume $=11 \&$ Issue $=6$

\section{INTRODUCTION}

English is now indisputably the language of international scholarship and research. It is globally accepted due to the proliferation of information and technological advancements in various fields in the medium of English. Therefore, the demands of the 21st century call for the abilities on the stakeholders to think critically, listen, speak, collaborate and communicate effectively (ASCD, 2008 Association for Supervision and Curriculum Development) in English. In 
Analyzing Common Language Errors in Classroom Communication of Engineering TeachersAn Empirical Study

particular, teachers working in Professional/Engineering Colleges are required to communicate effectively in English which involves developing the diction and idiom required to suit the specific subject/discipline. The teachers are also required to facilitate a positive learning atmosphere for students and encourage them to perform better.

Qualified teachers working in Engineering Colleges desirably should bring clarity, coherence coupled with enthusiasm to their classrooms. However, very often their expertise or mastery over the subject is marred by the lacunae in their communicative repertoire. A teacher's first year on the job is often found to be very difficult. According to research studies, student achievement tends to be significantly worse in the classrooms of first-year teachers though it rises in teachers' second and third years (Rivkin, Hanushek, \&Kain, 2005). The steep learning curve is hard not only on students, but also on the teachers themselves: 15 percent of young teachers leave the profession and another 14 percent change colleges after their first year, often as the result of feeling overwhelmed, ineffective, and unsupported (Ingersoll \& Smith, 2003; Smith \& Ingersoll, 2004).

Surveys and case studies offer compelling insights into the areas in which new teachers commonly struggle. By effectively addressing these areas, colleges can help new teachers improve their skills more quickly, thereby keeping them in the profession and contributing to raising student achievement. One of the main reasons in this context is the teacher's poor communication skills. Hence, the present study was conducted in three stages, namely,

- Analyzing Common English Language Errors in Classroom Communication through observations and video recordings in the Pre test and Post test.

- Comparison of pre test and post test findings

- Training in developing effective classroom communication skills using videos/lectures.

The above tests are elaborated in the following paragraphs.

\subsection{Analyzing Common English Language Errors in Classroom Communication through in the Pre test}

The data was collected by analyzing the sample recordings of 40 teachers working in Engineering colleges of three different colleges in the district of Warangal in the state of Telangana in India. The teachers were qualified with a Master's degree/Ph.D in their respective fields of expertise. Samples were collected from teachers teaching in Engineering, Humanities and Sciences background. The classroom observations revealed that the teachers have difficulty in the following language functions while teaching.

Table 1 Findings of classroom Observations in terms of Introduction, methodology

\begin{tabular}{|l|}
\hline $\begin{array}{l}\text { a. Describing Cause and Effect relations using transitional phrases and } \\
\text { linkers }\end{array}$ \\
\hline b. Using context specific vocabulary \\
\hline c. language expressions required to explain concepts, processes methods.etc. \\
\hline d. Use of collocations and Connectives \\
\hline e. Use of intra and inter sential linkers \\
\hline f. Speaking with precision and clarity \\
\hline j. Use of appropriate tense forms, etc. \\
\hline k. Language for paraphrasing and summarizing \\
\hline l. use of articles, prepositions and question tags. Pronunciation, Accent, \\
\hline n. Introduction with anecdotes,
\end{tabular}


o. use of visuals, symbols, imagery,

p. Improper use of blackboard trying to cover what they write Facing towards blackboard.

r. Use of chunks/ vocab: Expert opinion/ Quoting/ Mentioning things read or heard/

Mentioning sources/ Other people's experiences.

s.Personal /authentic experiences

Therefore, in order to help the teachers overcome problems related to classroom communication it was felt necessary to analyse the methodology of teaching in detail identifying some language parameters/tools for evaluation. These are explained in the following sections in the tabular form.

Table -1 explains how the teacher(T1 to T20) introduced the lesson/concepts to the class.

Table 1 Introduction 1. Unplanned/Insignificant2. Systematic and clear/Improved 3. Peripheral 4. Perfect /organised/planned (I)

\begin{tabular}{|l|l|l|l|l|l|l|l|l|}
\hline \multicolumn{1}{|c|}{ S.No } & \multicolumn{2}{l|}{$\begin{array}{l}\text { Recap/Questio } \\
\text { ning }\end{array}$} & \multicolumn{2}{l|}{$\begin{array}{l}\text { Enquiry/Affirma } \\
\text { tion }\end{array}$} & \multicolumn{2}{l|}{$\begin{array}{l}\text { Brain } \\
\text { storming }\end{array}$} & \multicolumn{2}{l|}{$\begin{array}{l}\text { Relevance of the } \\
\text { topic }\end{array}$} \\
\hline & Pre & Post & Pre & Post & Pre & Post & Pre & Post \\
\hline T1 Chemistry & 1 & 2 & 2 & 2 & 3 & 2 & 4 & 4 \\
\hline T2 Mathematics & 2 & 2 & 3 & 2 & 1 & 2 & 3 & 4 \\
\hline T3 Bio-Tech & 1 & 2 & 3 & 2 & 3 & 2 & 4 & 4 \\
\hline T4 Civil & 1 & 2 & 2 & 2 & 3 & 2 & 4 & 2 \\
\hline T5 ME & 1 & 2 & 3 & 2 & 3 & 2 & 4 & 2 \\
\hline T6 CSE & 1 & 2 & 3 & 2 & 3 & 2 & 3 & 2 \\
\hline T7 ECE & 1 & 2 & 3 & 2 & 1 & 2 & 3 & 2 \\
\hline T8 ECE & 1 & 2 & 3 & 2 & 3 & 3 & 3 & 2 \\
\hline T9 ME & 1 & 3 & 3 & 2 & 1 & 3 & 3 & 2 \\
\hline T10 Physics & 1 & 4 & 3 & 3 & 3 & 3 & 1 & 2 \\
\hline T11 Physics & 1 & 4 & 3 & 3 & 1 & 2 & 1 & 3 \\
\hline T12 Physics & 1 & 4 & 2 & 2 & 3 & 3 & 1 & 3 \\
\hline T13 Bio tech & 1 & 2 & 2 & 3 & 1 & 2 & 3 & 3 \\
\hline T14 CE & 1 & 4 & 3 & 2 & 3 & 3 & 3 & 3 \\
\hline T15 CE & 1 & 2 & 3 & 3 & 1 & 2 & 3 & 2 \\
\hline T16 Metallurgy & 1 & 2 & 3 & 2 & 3 & 3 & 4 & 3 \\
\hline T17 Metallurgy & 1 & 4 & 3 & 3 & 1 & 2 & 1 & 3 \\
\hline T18 English & 3 & 4 & 3 & 2 & 3 & 2 & 4 & 2 \\
\hline T19 English & 1 & 2 & 2 & 3 & 1 & 2 & 3 & 3 \\
\hline T20 Chemistry & 3 & 2 & 3 & 2 & 3 & 2 & 1 & 2 \\
\hline
\end{tabular}

Table -2 explains the methodology used by teacher in teaching a concept/theorem/ lesson

Table 2 Methodology/Explanation (M) in the Pre Test and Post Test 1. Systematic and clear 2. Well explained 3. Peripheral/ Insignificant/ unplanned 4. Evident 5.Very rarely6. Never

\begin{tabular}{|l|l|l|l|l|l|l|l|l|l|l|l|l|l|l|l|}
\hline \multicolumn{1}{|c|}{ S.No } & \multicolumn{2}{l}{$\begin{array}{l}\text { Data/ } \\
\text { Numbers }\end{array}$} & \multicolumn{2}{l|}{$\begin{array}{l}\text { Trends/De } \\
\text { rivations }\end{array}$} & \multicolumn{2}{l}{$\begin{array}{l}\text { Cause and } \\
\text { Effect }\end{array}$} & \multicolumn{2}{l}{$\begin{array}{l}\text { Compare } \\
\text { and Contrast }\end{array}$} & \multicolumn{2}{l}{$\begin{array}{l}\text { Questioning/ } \\
\text { Clarification/ } \\
\text { restating }\end{array}$} & \multicolumn{2}{l}{$\begin{array}{l}\text { Askingfor } \\
\text { opinions }\end{array}$} & \multicolumn{2}{l}{$\begin{array}{l}\text { Mannerisms } \\
\text { /Repetitive } \\
\text { phrases used }\end{array}$} \\
\hline & Pre & Post & Pre & Post & Pre & Post & Pre & Post & Pre & Post & Pre & Post & Pre & Post \\
\hline T1 Chem & 5 & 3 & 3 & 4 & 1 & 1 & 1 & 4 & 5 & 3 & 5 & 2 & 4 & 5 \\
\hline $\begin{array}{l}\text { T2 } \\
\text { Mathematics }\end{array}$ & 5 & 1 & 4 & 1 & 6 & 2 & 6 & 4 & 5 & 4 & 6 & 1 & 4 & 5 \\
\hline T3 Bio-Tech & 6 & 1 & 6 & 1 & 5 & 2 & 5 & 2 & 5 & 1 & 5 & 2 & 4 & 5 \\
\hline T4 Civil & 3 & 3 & 3 & 4 & 5 & 2 & 5 & 2 & 5 & 1 & 6 & 1 & 4 & 5 \\
\hline T5 ME & 3 & 1 & 3 & 1 & 3 & 2 & 3 & 2 & 3 & 1 & 5 & 1 & 4 & 5 \\
\hline
\end{tabular}


Analyzing Common Language Errors in Classroom Communication of Engineering TeachersAn Empirical Study

\begin{tabular}{|l|l|l|l|l|l|l|l|l|l|l|l|l|l|l|}
\hline T6 CSE & 3 & 2 & 3 & 4 & 3 & 1 & 3 & 2 & 3 & 2 & 5 & 2 & 4 & 5 \\
\hline T7 ECE & 5 & 3 & 3 & 1 & 3 & 2 & 3 & 5 & 3 & 2 & 6 & 2 & 4 & 5 \\
\hline T8 ECE & 5 & 1 & 3 & 4 & 3 & 1 & 3 & 2 & 3 & 2 & 6 & 3 & 4 & 5 \\
\hline T9 ME & 3 & 2 & 3 & 1 & 5 & 2 & 5 & 5 & 3 & 2 & 5 & 1 & 4 & 5 \\
\hline T10 Physics & 3 & 3 & 5 & 4 & 5 & 1 & 5 & 2 & 3 & 2 & 5 & 2 & 4 & 5 \\
\hline T11 Physics & 3 & 3 & 5 & 1 & 3 & 2 & 3 & 5 & 3 & 1 & 6 & 3 & 5 & 5 \\
\hline T12 Physics & 3 & 2 & 5 & 4 & 3 & 3 & 3 & 3 & 5 & 1 & 6 & 2 & 4 & 5 \\
\hline T13 Bio tech & 6 & 1 & 6 & 1 & 3 & 3 & 3 & 2 & 3 & 1 & 5 & 3 & 5 & 1 \\
\hline T14 CE & 3 & 1 & 5 & 4 & 5 & 1 & 5 & 3 & 5 & 2 & 6 & 1 & 4 & 5 \\
\hline T15 CE & 3 & 2 & 5 & 2 & 5 & 2 & 5 & 2 & 3 & 2 & 5 & 2 & 5 & 5 \\
\hline $\begin{array}{l}\text { T1 } \\
\text { Metallurgy }\end{array}$ & 6 & 3 & 3 & 2 & 5 & 3 & 5 & 1 & 3 & 1 & 6 & 3 & 4 & 5 \\
\hline $\begin{array}{l}\text { T17 } \\
\text { Metallurgy }\end{array}$ & 6 & 1 & 3 & 1 & 3 & 1 & 3 & 2 & 5 & 1 & 5 & 1 & 5 & 5 \\
\hline T18 English & 6 & 2 & 6 & 2 & 5 & 2 & 5 & 1 & 5 & 2 & 6 & 2 & 4 & 5 \\
\hline T19 English & 6 & & 6 & 4 & 5 & 3 & 5 & 1 & 5 & 2 & 4 & 3 & 5 & 5 \\
\hline $\begin{array}{l}\text { T20 } \\
\text { Chemistry }\end{array}$ & 3 & 2 & 0 & 1 & 3 & 1 & & 1 & 5 & 1 & 5 & 1 & 3 & 5 \\
\hline
\end{tabular}

Table -3 explains the use of technology enabled materials/sources used by the teachers in the classroom while teaching

Table 3 Technology Enabled Materials/Sources (TES) in the Pre Test and Post Test 1. Always 2. Occasionally 3. Never 4. Mostly

\begin{tabular}{|l|l|l|l|l|l|l|l|l|}
\hline \multicolumn{1}{|l|}{ S1.No } & \multicolumn{2}{l}{$\begin{array}{l}\text { Expert } \\
\text { Mentioning sources }\end{array}$} & \multicolumn{3}{l}{$\begin{array}{l}\text { Quoting } \\
\text { examples }\end{array}$} & \multicolumn{2}{l|}{$\begin{array}{l}\text { Citing real life } \\
\text { AV Aids } \\
\text { (Videos/Visuals/Black }\end{array}$} \\
\hline & Pre & Post & Pre & Post & Pre & Post & Pre & Post \\
\hline T1 Chem & 3 & 2 & 2 & 2 & 2 & 4 & 2 & 4 \\
\hline T2 Maths & 3 & 2 & 2 & 2 & 2 & 4 & 2 & 4 \\
\hline T3 Bio-Tech & 3 & 2 & 2 & 2 & 2 & 4 & 2 & 4 \\
\hline T4 Civil & 3 & 2 & 2 & 2 & 3 & 4 & 2 & 4 \\
\hline T5 ME & 3 & 2 & 3 & 2 & 3 & 4 & 2 & 4 \\
\hline T6 CSE & 3 & 2 & 3 & 2 & 3 & 4 & 2 & 4 \\
\hline T7 ECE & 3 & 2 & 2 & 2 & 3 & 4 & 2 & 4 \\
\hline T8 ECE & 3 & 2 & 3 & 2 & 3 & 4 & 2 & 4 \\
\hline T9 ME & 3 & 2 & 2 & 2 & 2 & 4 & 2 & 1 \\
\hline T10 Physics & 3 & 2 & 3 & 2 & 2 & 4 & 3 & 1 \\
\hline T11 Physics & 3 & 2 & 2 & 2 & 3 & 4 & 2 & 1 \\
\hline T12 Physics & 3 & 1 & 3 & 2 & 2 & 2 & 3 & 4 \\
\hline T13 Bio tech & 3 & 2 & 2 & 2 & 3 & 2 & 2 & 4 \\
\hline T14 CE & 2 & 1 & 3 & 2 & 2 & 2 & 3 & 2 \\
\hline T15 CE & 2 & 2 & 2 & 2 & 3 & 4 & 2 & 2 \\
\hline $\begin{array}{l}\text { T16 } \\
\text { Metallurgy }\end{array}$ & 2 & 1 & 3 & 2 & 2 & 2 & 3 & 2 \\
\hline $\begin{array}{l}\text { T17 } \\
\text { Metallurgy }\end{array}$ & 3 & 2 & 2 & 2 & 3 & 4 & 2 & 4 \\
\hline T18 English & 3 & 1 & 2 & 2 & 2 & 2 & 3 & 4 \\
\hline T19 English & 3 & 1 & 3 & 2 & 3 & 4 & 2 & 2 \\
\hline T20 Chem & 3 & 2 & 3 & 2 & 2 & 2 & 3 & 4 \\
\hline
\end{tabular}


Table 4 explains the aspects related to non verbal communication in the classroom while teaching

Table 4 Non Verbal Communication (NVC) in the Pre Test and Post Test 1. Well anchored and good eye contact 2. Bad eye contact and Posture 3. Monotonous 4. Occasionally 5. Judicious/Improved

\begin{tabular}{|c|c|c|c|c|c|c|c|c|c|c|c|c|c|c|}
\hline \multirow[t]{2}{*}{ Sl.No } & \multicolumn{2}{|c|}{ Eye Contact } & \multicolumn{2}{|c|}{ Posture } & \multicolumn{2}{|c|}{ Gestures } & \multicolumn{2}{|c|}{ Confidence } & \multicolumn{2}{|c|}{$\begin{array}{l}\text { Voice } \\
\text { Modulation }\end{array}$} & \multicolumn{2}{|c|}{$\begin{array}{l}\text { Interaction } \\
\text { /Moving }\end{array}$} & \multicolumn{2}{|c|}{$\begin{array}{l}\text { Use of Black } \\
\text { /White board }\end{array}$} \\
\hline & Pre & Post & Pre & Post & Pre & Post & Pre & Post & Pre & Post & Pre & Post & Pre & Post \\
\hline $\begin{array}{l}\text { T1 } \\
\text { Chemistry }\end{array}$ & 1 & 5 & 2 & 1 & 3 & 1 & 1 & 1 & 3 & 5 & 4 & 5 & 5 & 5 \\
\hline T2 Maths & 2 & 5 & 2 & 1 & 3 & 1 & 2 & 1 & 3 & 5 & 4 & 5 & 4 & 5 \\
\hline $\begin{array}{ll}\text { T3 } & \text { Bio- } \\
\text { Tech } & \end{array}$ & 1 & 5 & 2 & 1 & 3 & 1 & 1 & 1 & 3 & 5 & 4 & 5 & 5 & 5 \\
\hline T4 Civil & 2 & 5 & 2 & 1 & 3 & 5 & 2 & 1 & 3 & 5 & 4 & 5 & 5 & 5 \\
\hline T5 ME & 1 & 5 & 2 & 1 & 3 & 5 & 1 & 1 & 3 & 5 & 4 & 5 & 5 & 5 \\
\hline T6 CSE & 2 & 5 & 1 & 1 & 3 & 1 & 2 & 1 & 3 & 5 & 4 & 4 & 5 & 5 \\
\hline T7 ECE & 2 & 5 & 2 & 1 & 3 & 5 & 2 & 1 & 3 & 5 & 4 & 4 & 5 & 5 \\
\hline T8 ECE & 2 & 5 & 1 & 5 & 3 & 1 & 2 & 1 & 3 & 5 & 4 & 4 & 5 & 5 \\
\hline T9 ME & 2 & 5 & 2 & 5 & 3 & 5 & 2 & 1 & 3 & 3 & 4 & 5 & 5 & 5 \\
\hline $\begin{array}{l}\text { T10 } \\
\text { Physics }\end{array}$ & 2 & 5 & 1 & 1 & 3 & 1 & 2 & 1 & 3 & 5 & 5 & 5 & 5 & 5 \\
\hline $\begin{array}{l}\text { T11 } \\
\text { Physics }\end{array}$ & 2 & 5 & 2 & 5 & 3 & 1 & 1 & 1 & 3 & 3 & 5 & 4 & 4 & 5 \\
\hline $\begin{array}{l}\text { T12 } \\
\text { Physics }\end{array}$ & 2 & 4 & 1 & 1 & 3 & 5 & 2 & 1 & 3 & 3 & 5 & 4 & 5 & 5 \\
\hline $\begin{array}{ll}\text { T13 } & \text { Bio } \\
\text { tech } & \end{array}$ & 2 & 4 & 2 & 1 & 3 & 1 & 1 & 1 & 3 & 5 & 4 & 5 & 5 & 5 \\
\hline T14 CE & 1 & 5 & 1 & 5 & 3 & 1 & 2 & 1 & 3 & 3 & 4 & 4 & 5 & 5 \\
\hline T15 CE & 2 & 4 & 2 & 5 & 3 & 1 & 2 & & 3 & 5 & 5 & 5 & 5 & 5 \\
\hline $\begin{array}{l}\text { T16 } \\
\text { Metallurgy }\end{array}$ & 1 & 5 & 2 & 1 & 3 & 5 & 1 & 1 & 3 & 3 & 4 & 5 & 5 & 5 \\
\hline $\begin{array}{l}\text { T17 } \\
\text { Metallurgy }\end{array}$ & 2 & 4 & 2 & 1 & 3 & 4 & 2 & 1 & 3 & 3 & 5 & 5 & 4 & 4 \\
\hline $\begin{array}{l}\text { T18 } \\
\text { English }\end{array}$ & 1 & 5 & 2 & 1 & 3 & 5 & 1 & 1 & 3 & 5 & 4 & 5 & 4 & 4 \\
\hline $\begin{array}{l}\text { T19 } \\
\text { English }\end{array}$ & 2 & 4 & 2 & 1 & 3 & 5 & 2 & 1 & 3 & 5 & 5 & 5 & 4 & 4 \\
\hline $\begin{array}{l}\text { T20 } \\
\text { Chemistry }\end{array}$ & 2 & 5 & 2 & 1 & 3 & 4 & 2 & 1 & 3 & 3 & 4 & 5 & 5 & 4 \\
\hline
\end{tabular}

\subsection{Comparison of pre test and post test findings}

In the table given an analysis of the data using $\mathrm{T}$ - test and $\mathrm{F}$ test has been presented. The findings show that there has been a significant improvement in the teachers in terms of employing effective classroom strategies such as describing processes, explaining cause and effect relationships etc. 
Analyzing Common Language Errors in Classroom Communication of Engineering TeachersAn Empirical Study

Table 5

\begin{tabular}{|l|l|l|l|l|l|l|l|l|}
\hline \multirow{2}{*}{$\begin{array}{l}\text { Sl. } \\
\text { No }\end{array}$} & Stages & \multicolumn{2}{|l|}{ Mean } & \multicolumn{2}{l|}{ Standard Deviation } & t- test & F- test & $\begin{array}{l}\text { Correlation } \\
\text { coefficient } \\
\text { between x \& y }\end{array}$ \\
\cline { 3 - 8 } & $\begin{array}{l}\text { Pre test } \\
(\mathrm{x})\end{array}$ & $\begin{array}{l}\text { Post } \\
\text { test }(\mathrm{y})\end{array}$ & $\begin{array}{l}\text { Pre test } \\
(\mathrm{x})\end{array}$ & $\begin{array}{l}\text { Post test } \\
(\mathrm{y})\end{array}$ & & & & \\
\hline 1. & Introduction & 9 & 9.9 & 1.892 & 1.483 & 0.103 & 0.298 & -0.45 \\
\hline 2. & Methodology & 29.65 & 17 & 4.738 & 2.938 & $1.7 \mathrm{E}-11$ & 0.0435 & 0.02 \\
\hline 3. & $\begin{array}{l}\text { Technology } \\
\text { Enabled } \\
\text { resources }\end{array}$ & 9.619 & 9.810 & 2.334 & 2.822 & 0.813 & 0.403 & -0.099 \\
\hline 4. & $\begin{array}{l}\text { Non Verbal } \\
\text { Communication }\end{array}$ & 20.15 & 23.5 & 1.04 & 2.782 & $3.6 \mathrm{E}-05$ & $7.7 \mathrm{E}-05$ & 0.07 \\
\hline
\end{tabular}

(a) Introduction

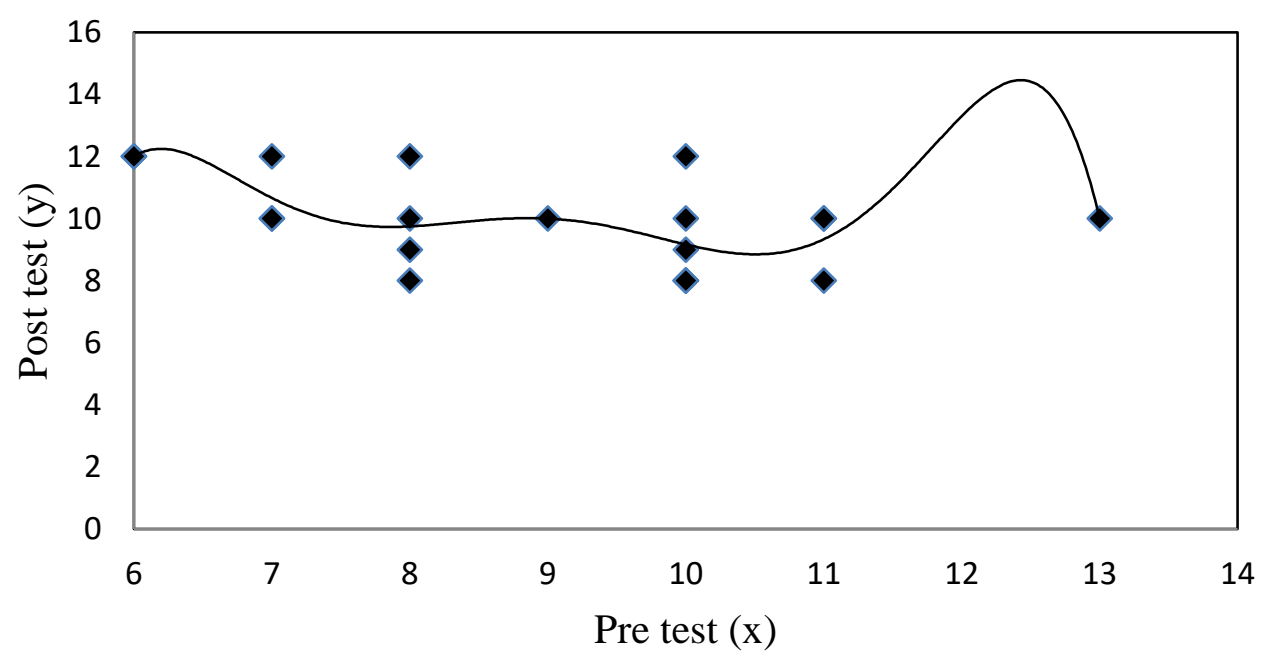

Figure 1

(b) Methodology

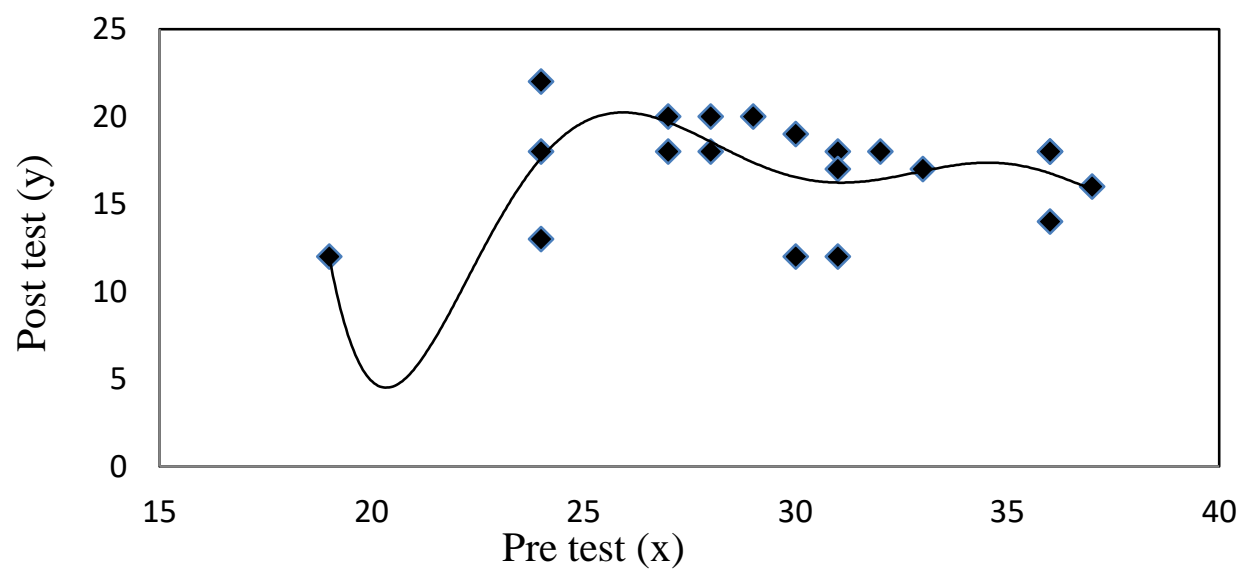

Figure 2 
(c) Technology Enabled resources

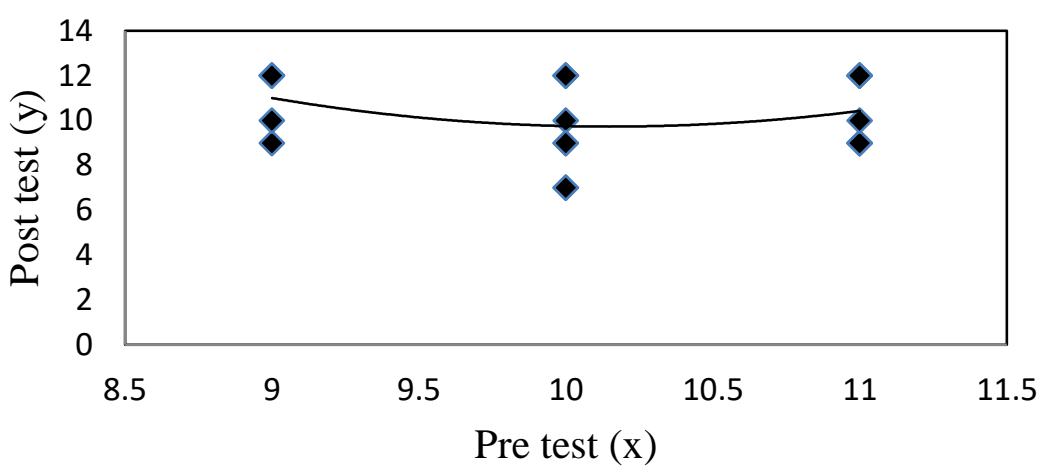

Figure 3

(d) Non Verbal Communication

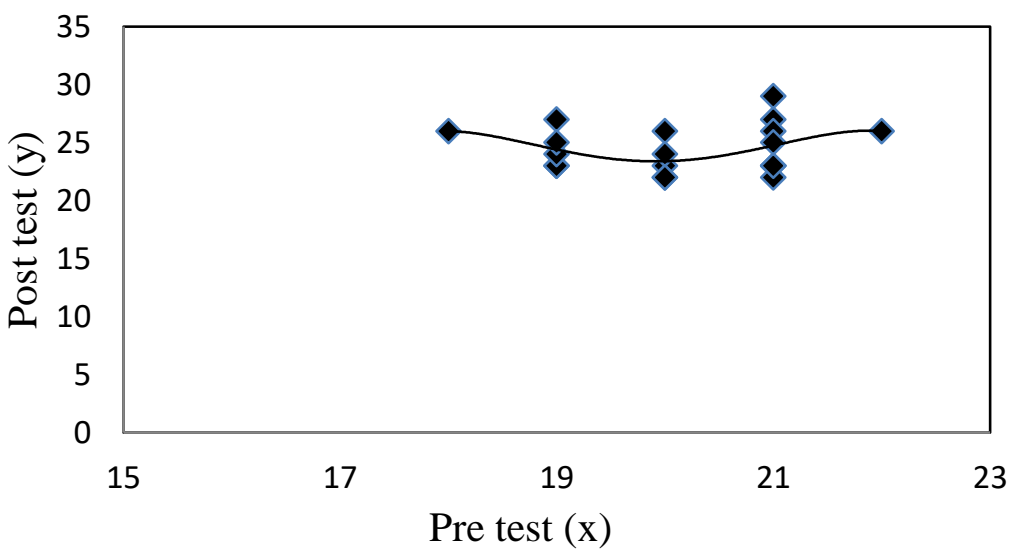

Figure 4

\section{Discussion of the Graphs}

Linear regression calculates an equation that minimizes the distance between the fitted line and all of the data points. In general, a model fits the data well if the differences between the observed values and the model's predicted values are small and unbiased. Before you look at the statistical measures for goodness-of-fit, you should check the residual plots. Residual plots can reveal unwanted residual patterns that indicate biased results more effectively than numbers. When your residual plots pass muster, you can trust your numerical results and check the goodness-of-fit statistics.

$\mathrm{R}$-squared is a statistical measure of how close the data are to the fitted regression line. It is also known as the coefficient of determination, or the coefficient of multiple determination for multiple regression.

The definition of R-squared is fairly straight-forward; it is the percentage of the response variable variation that is explained by a linear model. Or:R-squared $=$ Explained variation / Total variation $\mathrm{R}$-squared is always between 0 and $100 \%$ :

- $0 \%$ indicates that the model explains none of the variability of the response data around its mean.

- $100 \%$ indicates that the model explains all the variability of the response data around its mean. 
Analyzing Common Language Errors in Classroom Communication of Engineering TeachersAn Empirical Study

In general, the higher the R-squared, the better the model fits your data.

How well the equation $y=f(x)$ (solid lines) describes the scattered data (the 'fit'), is expressed as a correlation coefficient. The closer $\mathrm{R}^{2}$ is to 1.00 , the better the fit.

For (a) introduction

$y=-0.0152 x^{6}+0.8369 x^{5}-18.922 x^{4}+224.99 x^{3}-1483.5 x^{2}+5140.5 x-7299.3$ $\mathrm{R}^{2}=0.3561$

For (b) Methodology:

The regression line is $\mathrm{y}=0.00007 \mathrm{x}^{6}-0.01174 \mathrm{x}^{5}+0.86957 \mathrm{x}^{4}-33.95120 \mathrm{x}^{3}+736.35053 \mathrm{x}^{2}$ $-8,402.92235 \mathrm{x}+39,390.90780$

$\mathrm{R}^{2}=0.30267$

For $(C)$ The regression line is $y=0.964 \times 2-19.57 x+109.0$ with $R^{2}=0.085$

For $(d)$ The regression line is $y=-0.175 \times 4+13.94 \times 3-415.1 \times 2+5476 . x-26975 R^{2}=0.147$

\subsection{Training in developing effective classroom communication skills using videos.}

The teachers were made to watch videos related to language teaching and effective communication to enable them improve their communication skills. Videos related to body language, teacher motivation, behaviorist changes, using e learning materials and Flipped classroom techniques, effective classroom management, TED talks, etc. have been played. The researcher intervened for discussions and collaborative learning.

Post test findings of the study: The teachers were able to overcome language inhibitions in dealing with large classrooms. The findings show significant improvement in communication. These are listed below.

- Interact through Turn taking:, e.g. interrupting and responding to interruptions, appreciating

- Distinguish between informal and formal language expressions for example using polite expressions, opinion giving, polite disagreement and using indirect questions for asking opinions etc. They also learnt to support their arguments (e.g. giving examples, giving personal experience, giving statistics, quoting, giving reasons, explaining consequences, and predicting)

- Use of Collocations and Phrasal verbs: The teachers were able to use appropriate collocations such as refrain from, hesitate to, come forward, bring about

- Avoiding typical mistakes (e.g. "I am agree" and "How do you think about...?")

- Idioms/fixed expressions (e.g. "You took the words right out of my mouth") Sitting on the fence attitude

- Showing changes in position/view, Weighing up different views

- Constructing long or complex arguments (e.g. "There are three main reasons why I am against this")

- Replying to long or complex arguments (e.g. "In reply to your second point")

- Asking/Seeking clarification

- Voice modulations and articulation: pausing for thought, nodding, maintaining good eye contact, good posture etc. 


\section{CONCLUSION}

In a pedagogical context it becomes essential for the teachers to refine their skills to meet the growing challenges ahead. In the context of the present study, it is observed that a majority of the teachers working in Engineering Colleges are indispensably required to teach in English Language effectively. However, they encounter several problems in terms of classroom management, dealing with questions, preparing the lesson plans, delivering the lectures effectively using appropriate diction, dealing with nerves etc. They also face problems at lexical, syntactic and discourse levels. Though they have acquired necessary command over the subject / technical skills in their respective disciplines, they fail to employ appropriate communicative strategies in delivering their lectures effectively.

Therefore, keeping in view these major problems of the Engineering teachers in the area of English language use and communication, the present study attempted to analyse their common English language errors or problems faced by the inexperienced teachers in this field. The study also suggests remedial measures to enable them to understand and apply the language strategies /techniques for effective classroom teaching.

\section{REFERENCES}

[1] Chenoweth, K. (2009). How it's being done: Urgent lessons from unexpected schools. Cambridge, MA: Harvard Education Press.

[2] Fry, S. W. (2007). First-year teachers and induction support: Ups, downs, and in-betweens. The Qualitative Report, 12(2), 216-237.

[3] Hover, S. D., \& Yeager, E. A. (2004). Challenges facing beginning history teachers: An exploratory study. International Journal of Social Education, 19(1), 8-26.

[4] Ingersoll, R. M., \& Smith, T. M. (2003).The wrong solution to the teacher shortage. Educational Leadership, 60(8), 30-33.

[5] Mathews, J. (2011, December 18). New teacher decries lesson plan gap [blog post]. Retrieved from Class Struggle at The Washington Post at www.washingtonpost.com/blogs/classstruggle/post/new-teacher-decries-lesson-plan-gap/2011/12/17/gIQAt0C50O_blog.html

[6] McCormack, A., Gore, J., \& Thomas, K. (2006). Early career teacher professional learning. Asia-Pacific Journal of Teacher Education, 34(1), 95-113.

[7] Melnick, S., \& Meister, D. (2008). A comparison of beginning and experienced teachers' concerns. Educational Research Quarterly, 31(3), 39-56.

[8] Public Agenda. (2004). Teaching interrupted: Do discipline policies in today's public schools foster the common good? New York: Author.

[9] Rivkin, S. G., Hanushek, E. A., \&Kain, J. F. (2005). Teachers, schools, and academic achievement. Econometrica, 73(2), 417-458.

[10] Smith, T. M., \& Ingersoll, R. M. (2004). What are the effects of induction and mentoring on beginning teacher turnover? American Educational Research Journal, 41(3), 681-714. 